\title{
Analysis of complications of laparoscopic management of abdominal diseases related to extended indications
}

\author{
Kazimierz Rembiasz, Andrzej Bobrzyński, Andrzej Budzyński, Marcin Strzałka, Anna Gwóźdź, Marcin Migaczewski, Anna Zub \\ $2^{\text {nd }}$ Department of General Surgery, Collegium Medicum of Jagiellonian University, Kraków, Poland
}

Videosurgery and other miniinvasive techniques 2010; 5 (2): 53-59

DOI: 10.5114/wiitm.2010.14204

\begin{abstract}
Introduction: The introduction of minimally invasive procedures has changed the pattern of surgical complications. Some were only incidentally described in open surgery. Others significantly changed in character or incidence.

Aim: We present the incidence, character and dynamics of important complications of laparoscopic procedures within the entire period of application of this technique.

Material and methods: Patients operated on laparoscopically in the $2^{\text {nd }}$ Department of General Surgery of the Jagiellonian University between 1992 and $2009(n=8732)$ were included in the study. In order to follow the dynamics of complication rates the study period was divided into 3 sub-periods: 1) 1992-1997, 2) 1998-2003, 3) 2004-2009. There were 2343 laparoscopic procedures performed in the $1^{\text {st }}$ period, 3310 in the $2^{\text {nd }}$ and 3079 in the $3^{\text {rd }}$.

Results: The proportion of procedures other than cholecystectomy gradually increased: 1) $-22.79 \%$, 2) $-31.81 \%$, 3) $-40.05 \%$. Overall conversion rate was $2.91 \%$; in the $1^{\text {st }}$ period it was $3.97 \%$, in the $2^{\text {nd }} 1.81 \%$, and in the $3^{\text {rd }} 3.28 \%$. Complication-driven conversion rates were $0.60 \%, 0.27 \%$, and $0.26 \%$, respectively. Bleeding and biliary tree injuries were the most common causes. Complications requiring reoperations occurred in $0.48 \%$ of patients, and their incidence remained constant. Haemorrhage and intra-abdominal abscesses were observed most often. Use of laparoscopic technique in their management increased in consecutive periods from $20 \%$ in the $1^{\text {st }}, 45.83 \%$ in the $2^{\text {nd }}$, to $53.57 \%$ in the $3^{\text {rd }}$ time period.

Conclusions: The introduction of new advanced procedures did not increase overall complication rate. Change in their nature and more common use of laparoscopic technique in their management were noted.
\end{abstract}

Key words: complications of laparoscopy, common bile duct injuries, bleeding, intra-abdominal abscesses, re-laparoscopy.

\section{Introduction}

Any surgical intervention poses some risk of complications. It has been closely associated with surgery since its early days. Over the ages surgeons have tried to minimize the rate and severity of complications. Successive milestones in the development of surgery changed both the frequency and character of complications. Some are attributable to primary disease, risk factors and age. Hence, improvement depends on effective diagnosis and treatment affecting general health of the patient and on progress in anaesthesiology. However, some adverse events are directly related to operative technique. The introduction and popularization of a strategy for minimization of surgical access trauma at the end of the previous century has been one of the most significant issues in contemporary surgery. Minimally invasive techniques have resulted in new complications, hardly encountered in the open surgery era. Also, events found in the past started to occur at completely different rates. In the 
beginning, laparoscopy was criticized for its higher risk of complications, including severe ones, in comparison to open surgery. The learning curve undoubtedly played a role in this issue. In many centres it lasts relatively long, as when surgeons gain some experience in simple procedures, they gradually progress to more sophisticated ones. We now believe that in the centres experienced in laparoscopic techniques the complication rate does not significantly differ from classical surgery and sometimes is even noticeably lower. Obvious advantages of minimally invasive techniques have changed this perspective and laparoscopy has become a basic surgical tool.

\section{Aim}

The aim of this study was to present morbidity, type and change of the rate of significant complications of laparoscopic surgery with respect to changing complexity of the procedures. Additionally, methods of treatment of complications were assessed.

\section{Material and methods \\ Methods}

Retrospective analysis of the medical records of patients operated on with laparoscopy in the $2^{\text {nd }}$ Department of General Surgery, Collegium Medicum of Jagiellonian University in 1992-2009 was per-

Table I. Types of laparoscopic procedures performed in 1992-2009 in the 2nd Department of Surgery, Collegium Medicum of Jagiellonian University

\begin{tabular}{|c|c|c|c|c|}
\hline \multirow{2}{*}{\multicolumn{2}{|c|}{ Type of procedure }} & \multicolumn{2}{|c|}{ Number of patients } & \multirow{2}{*}{$\begin{array}{r}\text { Mean age } \\
\text { [years] }\end{array}$} \\
\hline & & $n$ & $\%$ & \\
\hline \multicolumn{2}{|c|}{ Cholecystectomy } & 5912 & 67.70 & 46.4 \\
\hline \multirow{7}{*}{ Other } & Appendectomy & 856 & 9.80 & 38.4 \\
\hline & Ulcer perforation & 95 & 1.09 & 41.3 \\
\hline & Hernia repair & 930 & 10.65 & 53.2 \\
\hline & Fundoplication & 135 & 1.55 & 44.4 \\
\hline & Splenectomy & 269 & 3.08 & 39.4 \\
\hline & Adrenalectomy & 228 & 2.61 & 52.1 \\
\hline & Other & 307 & 3.52 & 56.7 \\
\hline \multicolumn{2}{|l|}{ Total } & 8732 & 100 & 51.8 \\
\hline
\end{tabular}

formed. To analyse the dynamics of severe complications the material was divided into 3 six-year periods: $1^{\text {st }}-1992-1997,2^{\text {nd }}-1998-2003$ and $3^{\text {rd }}-2004-2009$. Indications for surgery in different time periods were analysed in two groups: cholecystectomies, other procedures.

Occurrence of intraoperative and early postoperative complications due to specific indications was assessed in each time period. Adverse events were categorized as:

- haemorrhage,

- biliary tree injury,

- intra-abdominal abscesses,

- other.

\section{Patients}

Patients operated on with laparoscopy $(n=8732)$ were included in the study. Mean age was $51.8 \pm 4.14$ years. There were 5692 women (65.19\%) and 3040 men (34.81\%). Mean women's age was $53.7 \pm 3.34$ years and men's $49.3 \pm 2.08$ years. Of the whole group, 5912 persons (67.7\%) were operated on for gallstones, and 2820 (32.3\%) underwent other procedures. There were 856 patients with acute appendicitis in the latter group, 95 with perforated peptic ulcer, 269 patients with haematological disorders requiring splenectomy, 228 patients with hormonally active or mute adrenal gland tumours, 135 patients with gastroesophageal reflux disease, 930 with inguinal hernia and 307 patients with other disease (Table I).

\section{Results}

During the $1^{\text {st }}$ period (1992-97) 2343 laparoscopic procedures were performed, 3310 in the $2^{\text {nd }}(1998-$ 2003), and 3079 in the $3^{\text {rd }}$ time period (2004-2009). Women were operated on more often in each of the study periods, although the percentage decreased gradually from $67.12 \%$ to $65.23 \%$ and $64.21 \%$, respectively. Mean age of both men and women steadily increased over time. Mean age of women was 47.6 years, 52.8 and 54.2 and of men 45.8, 48.9 and 51.3 years in the $1^{\text {st }}, 2^{\text {nd }}$ and $3^{\text {rd }}$ time period, respectively (Table II).

Cholecystectomy was the most frequent procedure irrespectively of the time-frame, although its proportion decreased progressively from 1809 procedures in the $1^{\text {st }}$ period $(77.21 \%), 2257$ in the $2^{\text {nd }}$ $(68.19 \%)$ to 1846 in the $3^{\text {rd }}(59.95 \%)$. The rate of more advanced laparoscopic procedures grew significantly, 
from $22.79 \%$ (534 patients) in the $1^{\text {st }}$ period, $31.81 \%$ (1059 patients) in the $2^{\text {nd }}$ to $40.05 \%$ (1233 patients) in the $3^{\text {rd }}$ period (Table III). The only procedure that was performed less often was laparoscopic hernia repair, with 399 procedures in the $1^{\text {st }}$ period, 320 in the $2^{\text {nd }}$ and 211 in the $3^{\text {rd }}$ one. The number of splenectomies, adrenalectomies and anti-reflux procedures performed increased significantly. Until 1997 no laparoscopic adrenalectomies were performed and splenectomy and Nissen fundoplication were done rather exceptionally. During 1998-2003, 72 splenectomies, 11 adrenalectomies and 32 anti-reflux procedures were completed. In the $3^{\text {rd }}$ period these procedures were much more common and their number increased, respectively, to 195 (splenectomy), 217 (adrenalectomy) and 93 (anti-reflux). Urgent procedures, such as appendectomy or suture of peptic ulcer perforation, rare on the rise of minimally invasive technique, have stabilized at a similar level in the $2^{\text {nd }}$ and $3^{\text {rd }}$ periods (Table III).

Of 8732 procedures begun with laparoscopy, 8478 were completed with this technique. In 254 patients $(2.91 \%)$ conversion to classic technique was necessary. The conversion rate of $3.97 \%$ in the $1^{\text {st }}$ time period dropped significantly $(p<0.001)$ to $1.81 \%$ in the $2^{\text {nd }}$ period only to increase again to $3.28 \%$ in the $3^{\text {rd }}$ one. Of all 254 conversions, 223 (2.55\% of a total of 8478 procedures) were due to technical reasons. Difficulties in anatomical identification, presence of inflammation, tough adhesions preventing safe preparation and identification of the structures,
Table II. Age and sex of patients operated on in each time period

\begin{tabular}{|llcc|}
\hline & \multicolumn{1}{l}{ Sex } & $n(\%)$ & $\begin{array}{c}\text { Mean age } \\
\text { [years] }\end{array}$ \\
\hline \multirow{3}{*}{$1^{\text {st }}$ period } & Men & $762(32.52 \%)$ & 45.8 \\
\cline { 2 - 4 } & Women & $1581(67.48 \%)$ & 47.6 \\
\cline { 2 - 4 } & Total & 2343 & 47.1 \\
\hline \multirow{2}{*}{$2^{\text {nd }}$ period } & Men & $1045(31.57 \%)$ & 48.9 \\
\cline { 2 - 4 } & Women & $2265(68.43 \%)$ & 52.8 \\
\cline { 2 - 4 } & Total & 3310 & 50.9 \\
\hline \multirow{2}{*}{$3^{\text {rd }}$ period } & Men & $1233(40.05 \%)$ & 51.3 \\
\cline { 2 - 4 } & Women & $1846(59.95 \%)$ & 54.2 \\
\cline { 2 - 4 } & Total & 3079 & 53.1 \\
\hline Total & & 8732 & 51.8 \\
\hline
\end{tabular}

fistulas and advanced cancer were the main reasons for conversion. In 31 patients $(0.36 \%)$ it was caused by intraoperative complications, requiring open repair. The most frequent ones were laparoscopically untreatable haemorrhages (14 patients), biliary tree injury diagnosed intraoperatively and repaired on laparotomy (13 patients), lesion (or suspected lesion) of the GI tract (3 patients) and injury of large vessels in the retroperitoneal space (1 patient). The complication-driven conversion rate was $0.6 \%$ in the $1^{\text {st }}$ peri-

Table III. Types of laparoscopic procedures performed in each time period categorised as basic procedures (cholecystectomy) and advanced procedures (other than cholecystectomy)

\begin{tabular}{|c|c|c|c|c|c|}
\hline \multicolumn{2}{|c|}{ Type of procedure } & $1^{\text {st }}$ period $(1992-1997)$ & $2^{\text {nd }}$ period $(1998-2003)$ & $3^{\text {rd }}$ period (2004-2009) & Total \\
\hline \multicolumn{2}{|c|}{ Cholecystectomy } & 1809 (72.21\%) & 2257 (68.19\%) & $1846(59.95 \%)$ & 5912 \\
\hline \multirow[t]{8}{*}{ Other } & & $534(22.79 \%)$ & 1053 (31.81\%) & $1233(40.05 \%)$ & \\
\hline & Appendectomy & 71 & 458 & 327 & 856 \\
\hline & Suture of perforation & 6 & 46 & 43 & 95 \\
\hline & Hernia repair & 399 & 320 & 211 & 930 \\
\hline & Fundoplication & 10 & 32 & 93 & 135 \\
\hline & Splenectomy & 2 & 72 & 195 & 269 \\
\hline & Adrenalectomy & 0 & 11 & 217 & 228 \\
\hline & Other & 46 & 114 & 147 & 307 \\
\hline \multicolumn{2}{|l|}{ Total } & 2343 & 3310 & 3079 & 8732 \\
\hline
\end{tabular}


Table IV. Incidence and causes of conversion in each time period

\begin{tabular}{|lcccccccc|}
\hline & \multirow{2}{*}{$\begin{array}{l}\text { Number of } \\
\text { procedures }\end{array}$} & \multicolumn{2}{c}{ Conversions (total) } & \multicolumn{2}{c}{ Conversions for technical reasons } & \multicolumn{2}{c|}{ Forced conversions } \\
\cline { 3 - 9 } & $n$ & $\%$ & $n$ & $\%$ & $n$ & $\%$ \\
\hline $1^{\text {st }}$ period & 2343 & 93 & 3.97 & 79 & 3.37 & 14 & 0.60 \\
\hline $2^{\text {nd }}$ period & 3310 & 60 & 1.81 & 51 & 1.54 & 9 & 0.27 \\
\hline $3^{\text {rd }}$ period & 3079 & 101 & 3.28 & 92 & 3.02 & 8 & 0.26 \\
\hline Total & 8732 & 254 & 2.91 & 223 & 2.55 & 31 & 0.36 \\
\hline
\end{tabular}

od (14 patients), dropped to $0.27 \%$ in the $2^{\text {nd }}$ period (9 patients) and remained at this level $(0.26 \%-8$ patients) in the $3^{\text {rd }}$ one (Table IV).

In the whole study major intraoperative complications were successfully treated with laparoscopy, without the need for conversion, in 4 patients. Three of them were perforations of the digestive tract (stomach, splenic flexure of the colon and small bowel). In 1 patient, the inferior vena cava injured during adrenalectomy was sutured laparoscopically.

Forty-two postoperative complications $(0.48 \%$ of patients) requiring re-operation occurred. Most often $(n=22)$ it was a haemorrhage, successfully treated with re-laparoscopy in 17 patients. Fourteen patients needed re-operation for abdominal abscess (7 post splenectomy, 3 after appendectomy and 4 after cholecystectomy). Nine of them were effectively treated with laparoscopy, while the others needed a classical procedure. In 4 patients biliary tree injury was unnoticed during primary laparoscopy. All of them were re-operated on with classical technique.
One patient needed open surgery for injury of the ureter, which occurred during resection of the retrocaecal appendix. One patient had re-laparoscopy on the day of primary surgery due to a foreign body left during abdominal hernia repair. The rate of complication-related re-interventions in the discussed time periods was $0.47 \%$ (11 patients) in the $1^{\text {st }}, 0.39 \%$ (13 patients) in the $2^{\text {nd }}$, and $0.58 \%$ (18 patients) in the $3^{\text {rd }}$.

Altogether intra- and early postoperative complications requiring surgical treatment occurred in 77 patients $(0.88 \%)$. In the $1^{\text {st }}$ period their rate was 1.11 (26 patients), in the $2^{\text {nd }}$ it was $0.73 \%$ (24 patients) and in the $3^{\text {rd }} 0.88 \%$ ( 27 patients). The rate of haemorrhage necessitating conversion or re-operation dropped from $0.6 \%$ in the $1^{\text {st }}$ time period to $0.3 \%$ in the $2^{\text {nd }}$ and 0.39 in the $3^{\text {rd }}$. Biliary tree injuries, which occurred in $0.34 \%$ of patients in the $1^{\text {st }}$ period, dropped to $0.12 \%$ in the $2^{\text {nd }}$ and $0.16 \%$ in the $3^{\text {rd }}$. Incidence of intra-abdominal abscesses of $0.09 \%$ during the $1^{\text {st }}$ period rose to $0.15 \%$ and $0.23 \%$, respectively (Table V). Of 77 patients requiring surgery for intra- or

Table V. Types of complications of laparoscopic procedures in each study period

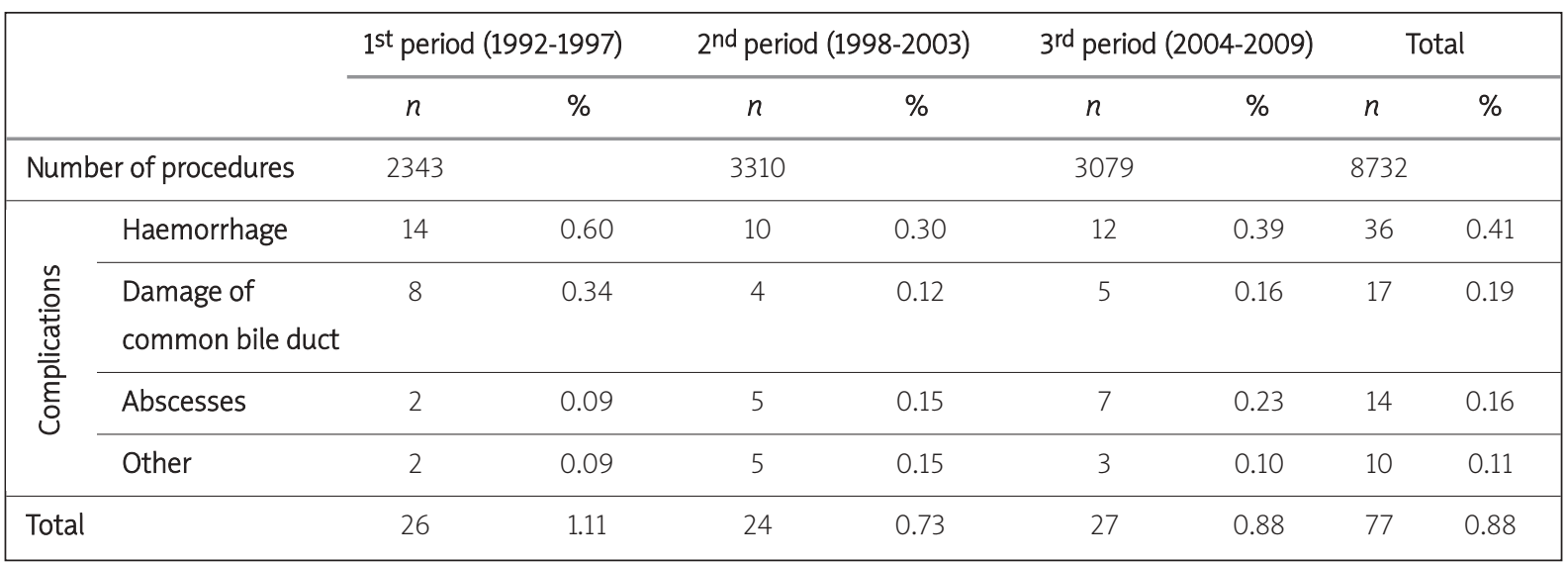


Table VI. Treatment of complications requiring surgical intervention

\begin{tabular}{|c|c|c|c|c|c|c|c|c|}
\hline & \multicolumn{2}{|c|}{$1^{\text {st }}$ period $(1992-1997)$} & \multicolumn{2}{|c|}{$2^{\text {nd }}$ period (1998-2003) } & \multicolumn{2}{|c|}{$3^{\text {rd }}$ period (2004-2009) } & \multicolumn{2}{|c|}{ Total } \\
\hline & $n$ & $\%$ & $n$ & $\%$ & $n$ & $\%$ & $n$ & $\%$ \\
\hline Number of procedures & 2343 & & 3310 & & 3079 & & 8732 & \\
\hline Complications & 25 & & 24 & & 28 & & 77 & \\
\hline Open intervention: & 20 & 80.0 & 13 & 54.17 & 13 & 46.43 & 46 & 59.74 \\
\hline - Forced conversions & 14 & & 9 & & 8 & & 31 & \\
\hline - Classical re-operations & 6 & & 4 & & 5 & & 15 & \\
\hline Laparoscopic intervention: & 5 & 20.0 & 11 & 45.83 & 15 & 53.57 & 31 & 40.26 \\
\hline - Primary laparoscopic & 1 & & 2 & & 1 & & 4 & \\
\hline $\begin{array}{l}\text { - Laparoscopic } \\
\text { re-operations }\end{array}$ & 4 & & 9 & & 14 & & 27 & \\
\hline
\end{tabular}

postoperative complications 31 (40.26\%) were successfully treated with laparoscopic technique. In the remaining 46 conversion $(59.74 \%)$ or re-operation laparotomy was necessary. In consecutive time periods the use of laparoscopy in treatment of complications increased gradually from $20 \%$ in the $1^{\text {st }}$ period to $45.83 \%$ and $53.57 \%$ in the $2^{\text {nd }}$ and $3^{\text {rd }}$ period. Today, the majority of complications of laparoscopic surgery that need re-intervention are dealt with using minimally invasive techniques (Table VI).

\section{Discussion}

The natural history of introduction of laparoscopic surgery usually begins with sceptical, and then more and more enthusiastic introduction of the first laparoscopic cholecystectomies. After gaining some experience these procedures are performed more frequently within the centre until nearly all, but suspected of cancer, patients with gallstones are initially qualified for laparoscopy. The time to achieve this point - often called the 'learning curve' - is characterized by a high rate of conversions and complications [1-7]. In the next stage, the number of procedures performed laparoscopically increases significantly and the spectrum of indications broadens. Year after year, the rate of technically advanced procedures, such as Nissen fundoplication, cardiomyotomy, splenectomy and adrenalectomy, increases [8-11]. In spite of proven experience, the complexity of new procedures and freer qualification of patients prevent the total number of adverse events from falling substantially $[8,10]$. This trend of gradually increasing difficulty of procedures when introducing laparoscopic surgery was also noted in this study. The percentage of procedures other than cholecystectomy increased significantly, from $22.79 \%$ during the first 6 years from introduction of the method to $31.81 \%$ and $40.05 \%$ today. What is interesting, the rate of laparoscopic hernia repairs decreased over time. Economic factors undoubtedly played a role in this phenomenon, but the technical complexity of this procedure and the need for general anaesthesia limit the indications. In many centres, after initial enthusiasm, these procedures are reserved for patients with bilateral and recurrent hernias.

Incidence of complications of laparoscopy according to the literature ranges from $0.35 \%$ to $10 \%[2,4$, $6,12]$. The rate of complications seen in our material $(0.88 \%)$ is rather low. This index was higher in the initial period $(1.11 \%)$ and then remained at a stable level $(0.73 \%$ and $0.88 \%)$ despite increased complexity and broadened indications for laparoscopic surgery.

The conversion rate is usually estimated at $1-5 \%$ and depends mostly on the experience of the surgeon and extent of surgery $[5,7,8,11,13-15]$. In our material the number of conversions (2.91\%) fell into this range. It should be underlined, however, that the majority of conversions $(2.55 \%)$ were planned, i.e. occurred for technical reasons and not due to complications. After temporary reduction to $1.54 \%$ in the $2^{\text {nd }}$ period, the conversion rate increased again to $3.02 \%$ due to a much higher number of difficult, complex procedures performed. This phenomenon is 
often described in the literature $[5,9,10,11,14,15]$. More importantly, complication-driven conversions were reduced significantly, from $0.6 \%$ in the $1^{\text {st }}$ period to $0.27 \%$ and $0.26 \%$.

When analysing complications attributable to laparoscopic surgery, we are obliged to discuss the most important and frequent one, i.e. biliary tree lesions. Associated with the most common laparoscopic procedure, it is extensively discussed in the literature $[1,3,16-19]$. Its occurrence ought not to exceed $0.2 \%$ in experienced centres. The rates usually fall between $0.13 \%$ and $0.59 \%[1,3]$. Brazilian authors have tried to explain a decrease in incidence of this severe complication at least partially with the experience of the operating teams. According to their publication, in centres performing fewer than 50 laparoscopic cholecystectomies a year the rate of biliary tree injuries was $0.77 \%$ and in those performing more than 500 it was only $0.16 \%$ [12]. Although the incidence of this complication dropped in our material from $0.34 \%$ to $0.12 \%$ and $0.16 \%$ in consecutive time periods, it should never be ignored as results of its treatment are not very optimistic and these patients need constant vigilance and subsequent interventions $[1,3,17,18]$.

Haemorrhage requiring intervention with open technique (conversion) or re-operation was the most frequent adverse event in the presented material. Its rate decreased from $0.6 \%$ to $0.3 \%$ and $0.39 \%$; nevertheless, it remains a serious clinical problem. In 14 patients haemorrhage resulted in conversion. In 6 of them the cystic artery or gall bladder groove was the source of bleeding. Most of them occurred early after introduction of laparoscopic technique, when the surgeon had no experience in assessment of the severity of this complication and safe management with minimally invasive methods. In 5 patients, massive haemorrhage from the splenic vessels (usually the vein) occurred. In the remaining 3 patients other lesions were found (injury of the aorta, inferior epigastric vessels and spleen). Of all 22 cases of bleeding that required re-operation, most often (12 patients) the origin was a trocar site. Only in 4 patients was the source of bleeding located within the surgical site (branch of the cystic artery, appendicular or splenic). In 2 patients haemorrhage from subcapsular haematoma of the liver and spleen occurred. In the remaining 6 , no active bleeding was found during re-intervention. After flushing the peritoneal cavity and placement of the drainage, no recurrence of haemorrhage was seen. It is worth stressing that today more and more of these complications can be successfully treated with laparoscopy and we observed a similar tendency in our material. The authors who discuss haemorrhage as a complication of laparoscopy emphasize the importance of meticulous assessment of haemostasis not only in the operative field, but also (or even in the first place) at the trocar sites [2, 5, 14, 19, 20]. Re-laparoscopy plays an important role in assessment and treatment of this complication. Second-look laparoscopy, when performed early, does not pose extra risk for the patient and allows for precise diagnosis and in many instances also for proper management $[2,5,19,20]$.

Infectious complications not associated with the trocar sites have risen to become an important issue. Herein, we present an increasing rate of intra-abdominal abscesses from $0.09 \%$ to $0.15 \%$ and $0.23 \%$. It may be related to the increasing level of difficulty of the procedures. Patients with acute cholecystitis are qualified for laparoscopic treatment more often and hence the risk of this complication is obviously higher. It could have been responsible for intra-abdominal abscesses in 4 of 14 cases in our material. As other authors have noticed, other emergency procedures, especially appendectomy for acute appendicitis, can add to this phenomenon [2, 20-23, 25]. Abscesses as a complication of laparoscopic appendectomy were seen in 3 patients. The increasing number of procedures in immunosuppressed patients (due to chronic steroid therapy or splenectomy) may also be an issue. Our experience shows that abscesses in this group of patients, although uncommon, can be extremely difficult to treat. Abscess in the post-splenectomy site was found in 7 patients [7, 21, 22].

It is not easy to comment on less frequent complications such as injuries of the GI tract [24, 26, 27] or large retroperitoneal vessels $[15,28]$. Although they affect the method significantly, they happen so rarely that it is difficult to find any epidemiological pattern. Similarly to our material, the literature on laparoscopy shows increasing use of this technique in treatment of complications [4, 10, 19, 24, 29]. These of course are not biliary tree injuries, but haemorrhage, abscess and some selected digestive tract injuries can be effectively treated with laparoscopic technique and minimum risk to the patient. In our material, application of minimally invasive techniques increased slowly from $20 \%$ in the $1^{\text {st }}$ period to $45.83 \%$ in the $2^{\text {nd }}$ and $53.57 \%$ nowadays. Such a trend can be seen in reports by other authors, who 
believe that the vast majority of complications of laparoscopy can be treated effectively with the very same technique [4, 10, 19, 24, 29].

\section{Conclusions}

During the study period, the number of procedures did not change significantly over time, yet the percentage of advanced procedures grew at the cost of cholecystectomy.

The introduction of more and more sophisticated procedures did not significantly affect the complication rate. Change of the character of complications was seen: the rate of haemorrhage and biliary tree injuries dropped, but intra-abdominal abscesses became more frequent.

Laparoscopic technique is used more often in treatment of complications.

\section{References}

1. Paczyński A, Koziarski T, Stanowski E, et al. Extrahepatic bile duct injury during laparoscopic cholecystectomy - a survey of 6873 patients. Med Sci Monit 2002; 8: 438-40.

2. Shamiyeh A, Wayand W. Laparoscopic cholecystectomy: early and late complications and their treatment. Langenbecks Arch Surg 2004; 389: 164-71.

3. Mahatharadol V. Bile duct injuries during laparoscopic cholecystectomy: an audit of 1522 cases. Hepatogastroenterology 2004; 51: $12-4$.

4. Konstadoulakis MM, Antonakis PT, Karatzikos G, et al. Intraoperative findings and postoperative complications in laparoscopic cholecystectomy: the Greek experience with 5,539 patients in a single center. J Laparoendosc Adv Surg Tech A 2004; 14: 31-6.

5. Bingener-Casey J, Richards ML, Strodel WE. Reasons for conversion from laparoscopic to open cholecystectomy: a 10-year review. J Gastrointest Surg 2002; 6: 800-5.

6. Budzyński P, Bobrzyński A, Biesiada Z, et al. Powikłania operacji laparoskopowych. Wideochirurgia i inne techniki małoinwazyjne 2005; 10: 2-4

7. Strzałka M, Budzyński A, Bobrzyński A, et al. Analiza częstości i przyczyn konwersji w chirurgii małoinwazyjnej. Pol Przegl Chir 2009; 81: 1159-69.

8. Gill J, Booth MI, Stratford J, et al. The extended learning curve for laparoscopic fundoplication: a cohort analysis of 400 consecutive cases. J Gastrointest Surg 2007; 11: 487-92.

9. Brody FJ, Chekan EG, Pappas TN, et al. Conversion factors for laparoscopic splenectomy for immune thrombocytopenic purpura. Surg Endosc 1999; 13: 789-91

10. Eto M, Harano M, Koga $\mathrm{H}$, et al. Clinical outcomes and learning curve of a laparoscopic adrenalectomy in 103 consecutive cases at a single institute. Int J Urol 2006; 13: 671-6.

11. Shen ZJ, Chen SW, Wang S, et al. Predictive factors for open conversion of laparoscopic adrenalectomy: a 13-year review of 456 cases. J Endourol 2007; 21: 1333-7.
12. Savassi-Rocha PR, Almeida SR, Sanches MD. latrogenic bile duct injuries. Surg Endosc 2003; 17: 1356-61.

13. Kama NA, Doganay M, Dolapci M, et al. Risk factors resulting in conversion of laparoscopic cholecystectomy to open surgery. Surg Endosc 2001; 15: 965-8.

14. Ishizaki Y, Miwa K, Yoshimoto J, et al. Conversion of elective laparoscopic to open cholecystectomy between 1993 and 2004. Br J Surg 2006; 93: 987-91.

15. Liu SI, Siewert B, Raptopoulos V, et al. Factors associated with conversion to laparotomy in patients undergoing laparoscopic appendectomy. J Am Coll Surg 2002; 194: 298-305.

16. Kostewicz W, Stanowski E. Kilka uwag o laparoskopowej cholecystektomii. Pol Przegl Chir 1994; 66: 197-211.

17. Krawczyk M, Patkowski W. Taktyka postępowania w jatrogennych uszkodzeniach dróg żótciowych. Pol Przegl Chir 2001; 1: 4-16.

18. Jędrzejczyk W, Jackowski M, Załudzki M, et al. Iatrogenic injuries of bile ducts during open and laparoscopic cholecystectomies. Digest Surg 1999; 16: 99.

19. Duszewski M, Szewczyk T, Mandryka Y, et al. Rare haemorrhagic complications of laparoscopic cholecystectomy. Videosurgery and other miniinvasive techniques 2009; 4: 131-4.

20. Wirkowski A, Pesta W. Pułapki cholecystektomii laparoskopowej - doświadczenia własne. Wideochirurgia i inne techniki małoinwazyjne 2008; 3: 179-85.

21. Hadasik D, Majewski E, Zaniewski M. Ropień podprzeponowy. Późne powikłanie cholecystektomii laparoskopowej. Opis przypadku. Wideochirurgia i inne techniki małoinwazyjne 2006; 1: 43-5.

22. Głowacki J, Stefaniak T, Gruca Z. Zakażenie miejsca operowanego w chirurgii wideoskopowej i endoskopii. Wideochirurgia i inne techniki małoinwazyjne 2008; 3: 10-6.

23. Mitura K, Romańczuk M. Konsekwencje przypadkowego pozostawienia złogów po cholecystektomii laparoskopowej. Wideochirurgia i inne techniki małoinwazyjne 2007; 2: 79-81.

24. Kot M, Głuszek S, Matykiewicz J, et al. Cholecystektomia laparoskopowa - czy jest to bezpieczna metoda operacyjna? Doświadczenia własne. Wideochirurgia i inne techniki małoinwazyjne 2006; 1: 113-20.

25. Strzałka M, Bobrzyński A, Budzyński A, et al. Open or laparoscopic appendectomy? Videosurgery and other miniinvasive techniques 2009; 4: 110-4.

26. van der Voort M, Heijnsdijk EA, Gouma DJ. Bowel injury as a complication of laparoscopy. Br J Surg 2004; 91: 1253-8.

27. Bartnicki J, Sikora J, Tylko M. Uszkodzenie jelita przy wprowadzaniu pierwszego trokaru u pacjentek po przebytych operacjach brzusznych. Wideochirurgia i inne techniki małoinwazyjne 2008; 3: 35-8.

28. Bierca J, Kowalski B, Kosim A, et al. Jatrogenne śmiertelne powikłania po cholecystektomii laparoskopowej. Wideochirurgia i inne techniki małoinwazyjne 2006; 1: 10-2.

29. Ros A, Haglund B, Nilsson E. Reintervention after laparoscopic and open cholecystectomy in Sweden 1987-1995: analysis of data from a hospital discharge register. Eur J Surg 2002; 168: $695-700$ 